\title{
The Impact of Teaching Critical Thinking Skills on Reading Comprehension of Iranian EFL Learners
}

\author{
Mansoor Fahim \\ Department of Foreign Languages and Literature, Allameh Tabatabaie University, Tehran, Iran \\ Email: dr.mfahim@yahoo.com \\ Maryam Sa'eepour \\ Department of Foreign Languages and Literature, Khatam State University, Tehran, Iran \\ Email: maryam.saiepour@gmail.com
}

\begin{abstract}
In line with the studies confirming the positive relationship between critical thinking ability and language proficiency, this study intended to investigate the impact of teaching critical thinking skills on reading comprehension ability, as well as the effect of applying debate on critical thinking of EFL learners. For this purpose 60 intermediate students were assigned to two experimental and control groups after being homogenized through a Nelson test. Afterwards, a reading comprehension and a critical thinking appraisal pretest were administered to the two groups. During the term the experimental group received 8 sessions of treatment using debate as a classroom activity. To compare the two groups they were given the same tests as a posttest.The analysis of collected data showed significant difference between the two groups on reading comprehension test, but the difference on critical thinking test was non-significant. However, the results indicate that teaching critical thinking skills in EFL context can improve language learning. The study has implication for course designers, teachers and students.
\end{abstract}

Index Terms — critical thinking, debate, argumentation, reading comprehension

\section{INTRODUCTION}

Despite all efforts and costs of foreign language teaching in Iran, students suffer from difficulties in language learning skills. The problem appears to be in educational system that teachers, traditionally, do their best to teach 'what to think' rather than 'how to think' (Shuffersman, 1991) effectively about the subject matters which is termed as critical thinking.

In most educational systems, as Paul (1990) says, students gain lower order learning which is associative, and rote memorization resulting in misunderstanding, prejudice, and discouragement in which students develop techniques for short term memorization and performance. These techniques block the students' thinking seriously about what they learn.

Unfortunately, the situation in Iran is not different. Teachers, based on traditional teaching, disregard the learners' views and opinions, not giving them the chance to express themselves. Consequently, students do not learn to use their thinking skills.

The issue of incorporating critical thinking skills in education has raised many contradictory ideas about whether critical thinking can be taught or not. A variety of approaches and models to teaching, measuring and assessing critical thinking skills and abilities have been developed. In addition, teaching critical thinking skills has raised many issues such as culture, emotion, transferability and generalizability of the taught skills which are discussed and answered by the experts. Despite all contradictory ideas and beliefs on teaching critical thinking skills, however, everyone agrees that thinking critically is the major goal of education (Reed, 1998).

Having in mind that Iranian students are not educated as critical thinkers in their first language educational system, providing them with an appropriate context to foster critical thinking dispositions in foreign language setting is of crucial importance. As students do not display the elements of critical thinking in language skills, it is highly worth of investigation to find out whether teaching critical thinking skills could help the students improve their language proficiency. This study provides the experts in the field of language teaching with information about the relationship between critical thinking and learners' performance on reading comprehension texts applying critical thinking method, debate. It yields a realm of study for researchers who are interested in critical thinking and its relationship with language skills. Therefore the purpose of this study is to answer the following questions:

1. Does teaching critical thinking skills have any significant effect on improving reading comprehension of EFL learners?

2. Does participation in EFL classroom debate increase critical thinking ability? 


\section{LITERATURE REVIEW}

According to Reed (1998), the broad concept of critical thinking has brought about different definitions and terminologies by scholars. He says the lack of consensus on the definition of critical thinking and also its terminology has rested in the grounding of various theories and models in two distinct disciplines, psychology and philosophy. Philosophers have tended to focus on the nature and products of critical thinking, while psychologists have concentrated on the process of cognition, and seeking the conclusion in empirical research. On the other hand, some educators (Kuhn, 1992; Kurfiss, 1988; Marzano et al., 1988; Quellmalz, 1987; Weinstein, 1995, cited in Reed, 1998) have drawn on both psychology and philosophy to develop a rigorous theory of critical thinking for teaching.

Halvorsen (2005) also adds critical thinking is not an easy concept to define, as it can mean quite different things to different people in different contexts and cultures. Nevertheless, instructors can incorporate some of its key elements in their classrooms. He defines critical thinking as: "to think critically about an issue is to consider that issue from various perspectives, to look at and challenge any possible assumptions that may underlie the issue and to explore its possible alternative." (p.1)

Considering the breadth of the concept of critical thinking, Wright (2002) seeks an appropriate definition by means of clarifying the concept of critical thinking and determining what problem the definition should help to solve. For the purpose of teaching, for example, the definition should help the teachers teach and assess critical thinking in school classrooms. Thus, the definition is intended to "preserve the core meaning of the original concepts used to define critical thinking." (p. 41)

Supporting the necessity of teaching critical thinking skills in EFL contexts, Kabilan (2000) says the idea that language learners can be proficient by mastering the mechanisms of language was overshadowed by communicative approach in 1950s, emphasizing that learners become proficient by using the language not learning about language. Today it is strongly believed that using language and knowing the meaning don't lead the learners to be proficient. They need to display creative and critical thinking through the language to express and support their ideas creatively and critically. However, he continues, critical thinking skills should not be taught separately but incorporated in the curriculum.

Throughout the literature Richard Paul (2004) stresses the connection between critical thinking and reading comprehension. As he states, "The reflective mind improves its thinking by reflectively thinking about it. Likewise, it improves its reading by reflectively thinking about how it is reading..." Facione (1992) also suggests there is a significant correlation between critical thinking and reading comprehension. His quotation follows "Improvements in one are paralleled by improvements in other." (p.18)

Viewing reading comprehension as a vital part of second language curriculum, Barnett (1989) describes several reasons for its importance: It remains an important goal in many programs; it can be maintained after students complete formal language study; and it fosters the development of literacy skills. Some of the mental skills employed in reading comprehension, as Grabe (1991) states, are inference, analysis, synthesis, and evaluation which are what experts include "as being at the very core of critical thinking" (Facione, 1992).

\section{Debate}

Debate is considered as a method of critical thinking and reasoned decision making. It provides educational opportunities to improve critical thinking. Freeley and Steinberg (2000: 4) define debate as "the process of inquiry and advocacy, a way of arriving at a reasoned judgment on a proposition." As they say, "since classical times, debate has been one of the best methods of learning and applying the principles of critical thinking" (p.1). They continue, we conduct much of our communication in the form of debate whether in the form of "intrapersonal communication" when we have conflict with ourselves weighing the pros and cons in our minds, or " interpersonal communication", in which we take part in an argument to make a decision or influence the decisions of others.

Studies on debate show a significant effect on critical thinking proficiency. The studies show that debaters significantly outscore non-debaters on critical thinking tests. It is "an educational activity that provides students with opportunities to develop proficiency in writing, thinking, speaking, reading, and listening." (Freely, 2000, p.29) Barfield (1989) also concluded that participation of high school students in debate positively correlates with significant gains in cumulative GPA.

A study conducted by Fukuda (2003) on Japanese students showed that "before the debate only $30.8 \%$ of students were not afraid of expressing their opinions when they were not the same as others. After the debate this figure rose to 56.7\%." Davidson (1995) also concluded from his study, with practicing debate students showed obvious progress in expressing and defending their ideas.

\section{Methodology}

\section{A. Participants}

The subjects for the current study were chosen from among 75 female EFL learners. They were similar in educational background, family and social status, studying English at the intermediate level in English Institute in Karaj Iran. They ranged in age from 16 to 19 years. Most of the participants were high school students, and few of them were freshmen at university. In order to check their proficiency level, a Nelson proficiency test was run. According to the result of 
Nelson test 60 learners were assigned to two groups of control and experimental. The students in each group were $(\mathrm{n}=$ $30)$.

\section{B. Instrumentation}

The following instruments were used in this study:

\section{Homogeneity Test}

A Nelson 150D English proficiency test was administered to ensure the homogeneity of the subjects. It consisted of 50 multiple choice items of knowledge of English structures. The time allotted to take this test was 25 minutes and the scoring was estimated out of 50 . Additionally, to estimate whether these 60 learners were homogeneous regarding their proficiency level, an independent t-test was run. Based on the obtained scores and through the independent $\mathrm{t}$-test, it was confirmed that the two groups enjoyed similar level of language proficiency.

2. Reading Comprehension Test

A validated reading comprehension test was administered as the pre-test and post-test. The test included 5 passages, followed by 25 items. Therefore, the scoring was calculated out of 25 . This test was administered to both experimental and control group. The reliability, validity, item facility, and item discrimination of this test was determined in the piloting phase of study. The reliability of the test scores was estimated through KR-21 formula as $(r=.86)$.

\section{Critical Thinking Test}

The critical thinking appraisal test (CTA) that measures some of the important abilities involved in critical thinking including 30 items was administered to the subjects as pre-test and post-test before the treatment to measure their critical thinking ability, and after the treatment to measure any changes in subjects' critical thinking ability through using debate. The Cronbach Alpha coefficient for the reliability was .89. The (CTA) was adapted to a 5-point scale ranging from always to never. Therefore, the scores ranged within 30 to 150 . The participants' score were calculated by adding the numbers of the scores.

\section{Material for Debate}

Considering the purpose of this study, and the strong evidence that debate is the best method of learning and applying the principles of critical thinking (Freely, 2000), eight highly controversial topics were chosen by the researcher. The topics have been informal and controversial in style, selected from the books Mosaic 1 for reading by Wegmann and Knezevic (2002), For and Against by Alexander (1973), and Landmark by Haines and Stewart (2000) based on the students' interest. Then they were simplified and updated using the internet sites to be suitable for the intermediate EFL students. The rationale behind the choice of these topics is that debate topics should be highly controversial. If there is agreement on the topic there would be no arguments, hence, no debate.

\section{Procedure and Design}

In this study a quasi-experimental non randomization control group design was used. In order to test the research hypothesis of this study the following steps were taken. To ensure the homogeneity of the participants in terms of language proficiency the standard Nelson 150D test was run at the outset of the study to 75 students. From the 75 students, 60 were assigned to two groups of control and experimental. The number of subjects in each group was $(n=30)$. Then they were given a reading comprehension test to evaluate their comprehension of written materials. Along with the reading comprehension test they were given a critical thinking appraisal test to check their critical thinking ability before the treatment. After the treatment the same tests were administered to determine any probable changes in the experimental group.

\section{Treatment}

After the pretest, 15 topics were simplified and given to the experimental group to choose 8 of them based on their interest. As Halvorsen (2005) et al suggest, choosing topics appropriate to the interests of the students is essential. After selecting 8 of them, they were given to the students, one per week. The researcher followed the steps offered by Halvorsen (2005) to hold the debate in the classroom. The first step was to introduce the topic to the students and give them the texts to take home to do research on, and gather the relevant information about. It is widely suggested that having knowledge about a debatable topic is the essential prerequisite for holding a debate. As Willingham (2007) holds, research of cognitive science shows that "the process of thinking is intertwined with the domain knowledge." Thus, it was constantly stressed that they had to equip themselves with relevant knowledge from internet, books, magazines, newspapers, and then share the collected information with their parents, teachers, and friends, to evaluate the evidence on the issue. Then they had to come to the class with lists of pros and cons of the issue. In the next step, the students were divided into small groups to share their opinions and think about the potential arguments that might come from the other side. This process teaches the students how to cooperate which promotes critical thinking. Then the debaters were divided into two sides as affirmative and negative. One of the students first would introduce the topic clearly and define the concepts accurately to remove any misconception about the exact meaning of the words. According to Djuranovic (2003), defining the terms in debate is very important because they determine the topic of the debate and its limitation. In the next step, the debate would take place and the debaters would present their opinions through argumentation. After exchanging opinions, the instructor would follow up the debate with a summary of the students' opinions and views, assessing the strengths and weaknesses, let the students express their opinions on which side was more convincing. This 
part is important because it helps the students to understand that the process of thinking and debate can lead to a real result (Halvorsen, 2005). After each session the students would give a piece of writing of the overall conclusion of the class and their final view of the issue. At the end of the debate students gain scores based on the quality of their reasoning. In the debate session the instructor tried to teach the students how to distinguish between facts and judgments or opinions, how to prove their claims based on examples, common sense, statistic, and expert opinions. They learned to start the argument with "I think/believe that ... because ... therefore ..." (Krieger, 2005, p. 2-3).

At the end of the experiment the appraisal critical thinking test and reading comprehension test which were used at the pre-test were employed again for both groups to determine the discrepancies between the two groups, to probe the probable positive effect of debate on critical thinking ability, and to find out the relationship between critical thinking ability and reading comprehension.

\section{RESULTS}

\section{A. Nelson Homogeneity Test}

The results of the present study as displayed in tables 1,2, and 3, indicate the homogeneity of the two groups in terms of language proficiency, reading comprehension and critical thinking ability on the pretest. The mean scores for the experimental and control groups as displayed in table 1 are 19.13 and 18.90 respectively. The two groups enjoy homogeneous variances, -- 5.024 and 5.032--i.e. the two groups are selected from the same population.

TABLE 1:

DESCRIPTIVE STATISTICS NELSON

\begin{tabular}{|l|l|l|l|l|l|}
\hline & GROUP & $\mathrm{N}$ & Mean & Std. Deviation & Std. Error Mean \\
\hline \multirow{2}{*}{ NELSON } & EXPERIMENTAL & $\mathbf{3 0}$ & $\mathbf{2 8 . 0 0}$ & $\mathbf{5 . 0 2 4}$ &. $\mathbf{9 1 7}$ \\
\cline { 2 - 6 } & CONTROL & $\mathbf{3 0}$ & $\mathbf{2 5 . 8 3}$ & $\mathbf{5 . 0 3 2}$ &. $\mathbf{9 1 9}$ \\
\hline
\end{tabular}

\section{B. Reading Comprehensions Pre-test}

Table 2 displays the homogeneity of the two groups in terms of reading comprehension through an independent $\mathrm{t}$-test. The mean scores for the two groups as shown in table 2 are 19.13 and 18.90. The homogeneous variances, 3.093 and 3.346 indicates the homogeneity of the groups.

TABLE 2:

DESCRIPTIVE STATISTICS READING COMPREHENSION PRETEST

\begin{tabular}{|l|l|l|l|l|l|}
\hline & GROUP & $\mathrm{N}$ & Mean & Std. Deviation & Std. Error Mean \\
\hline \multirow{2}{*}{ RCPRE } & EXPERIMENTAL & $\mathbf{3 0}$ & $\mathbf{1 9 . 1 3}$ & $\mathbf{3 . 0 9 3}$ & $\mathbf{. 5 6 5}$ \\
\cline { 2 - 6 } & CONTROL & $\mathbf{3 0}$ & $\mathbf{1 8 . 9 0}$ & $\mathbf{3 . 3 4 6}$ & $\mathbf{. 6 1 1}$ \\
\hline
\end{tabular}

\section{CT Pre-test}

Table 3 displays the homogeneity of the two groups in terms of critical thinking ability pretest. The mean scores for the two groups as shown in table 3 are 96.10 and 97.83. The homogeneous variances, 13.087 and 13.483 indicate the homogeneity of the groups.

TABLE 3:

Descriptive Statistics CRITICAL Thinking Pretest

\begin{tabular}{|l|l|l|l|l|l|}
\hline & GROUP & $\mathrm{N}$ & Mean & Std. Deviation & Std. Error Mean \\
\hline \multirow{2}{*}{ CTPRE } & EXPERIMENTAL & $\mathbf{3 0}$ & $\mathbf{9 6 . 1 0}$ & $\mathbf{1 3 . 0 8 7}$ & $\mathbf{2 . 3 8 9}$ \\
\cline { 2 - 6 } & CONTROL & $\mathbf{3 0}$ & $\mathbf{9 7 . 8 3}$ & $\mathbf{1 3 . 4 8 3}$ & $\mathbf{2 . 4 6 2}$ \\
\hline
\end{tabular}

\section{Reading Comprehension Post-test}

Tables 4 and 5 respectively display the significant difference between experimental and control groups in reading comprehension, but non- significant difference on critical thinking appraisal test after treatment.

TABLE 4:

DESCRIPTIVE STATISTICS READING COMPREHENSION POSTTEST

\begin{tabular}{|l|l|l|l|l|l|}
\hline \multirow{2}{*}{ RCPOST } & GROUP & $\mathrm{N}$ & Mean & Std. Deviation & Std. Error Mean \\
\cline { 2 - 6 } & EXPERIMENTAL & $\mathbf{3 0}$ & $\mathbf{2 1 . 6 7}$ & $\mathbf{2 . 4 6 8}$ & $\mathbf{. 4 5 1}$ \\
\cline { 2 - 6 } & CONTROL & $\mathbf{3 0}$ & $\mathbf{1 9 . 2 3}$ & $\mathbf{3 . 6 4 5}$ & $\mathbf{. 6 6 6}$ \\
\hline
\end{tabular}

\section{E. CT Post-test}


As displayed in table 4 the mean scores of experimental and control groups are respectively 21.67 and19.23. It can be concluded that teaching critical thinking skills has a significant effect on improving reading comprehension of EFL learners.

TABLE 5:

DESCRIPTIVE STATISTICS CRITICAL THINKING POSTTEST

\begin{tabular}{|l|l|l|l|l|l|}
\hline & GROUP & $\mathrm{N}$ & Mean & Std. Deviation & Std. Error Mean \\
\hline \multirow{3}{*}{ CTPOST } & EXPERIMENTAL & $\mathbf{3 0}$ & $\mathbf{9 8 . 5 0}$ & $\mathbf{1 6 . 0 2 1}$ & $\mathbf{2 . 9 2 5}$ \\
\cline { 2 - 6 } & CONTROL & $\mathbf{3 0}$ & $\mathbf{9 6 . 3 7}$ & $\mathbf{1 5 . 3 8 4}$ & $\mathbf{2 . 8 0 9}$ \\
\hline
\end{tabular}

Table 5 displays the descriptive statistics for the two groups on the Critical Thinking test. The mean scores for the experimental and control groups are 98.50 and 96.37 respectively.

\section{DISCUSSION}

To support the result in terms of the first question that proves the impact of teaching critical thinking skills on reading comprehension it is necessary to state the views of some cognitive experts regarding these two variables. Some of the mental skills employed in reading comprehension, as Celce-Murcia (2001) quotes Grabe (1991), are inference, synthesis, analysis, and evaluation which are what experts include as being at the very core of critical thinking. "As to the cognitive skills here is what experts include as being at the very core of critical thinking: interpretation, analysis, evaluation, inference, explanation, and self- regulation."(Facione, 1992, p.4)

In this regard, taking the definition of reading comprehension by Dorothy Durkin (1993), "intentional thinking during which meaning is constructed through interactions between text and reader", this construction of meaning during reading is "a complex merger of skills, prior knowledge and text mediated by the language skills, motivation and interest of the reader" (Collins, Gambrell, \& Pressley, 2002; Almasi, 2002, and Cambourne, 2002, cited in Robinson, 2006, p.32), which according to Sweet and Snow (2002, in Robinson, 2006, P.32) "covers the full spectrum of Bloom's taxonomy in critical thinking including knowing facts, understanding concepts, application, analysis, synthesis, and evaluation". Thus the above claim has been crystallized in the significant improvement of experimental group in reading comprehension. As it can be seen critical thinking and comprehension both are cognitive abilities having cognitive skills in common so that improving the first can contribute to the improvement of the other--reading comprehension. This supports the purpose of the study that teaching critical thinking skills has a positive effect on reading comprehension.

The statistical analysis on comparing the mean scores of the experimental and control groups on the critical thinking posttest, however, did not indicate a significant difference between the two groups. This lack of significant difference led the researcher to examine the differences between the mean scores in pre/posttests of the experimental and control groups. As table 3 in the above section shows the experimental and control groups' mean scores on the pretest of critical thinking were respectively 96.10 and 98.73 , while these mean scores on the posttest (table 5) were respectively 98.50 and 96.37. This amount of increase in the mean scores of experimental group in the posttest-- 96.10 to 98.50-- indicates the trend in the improvement of students' critical thinking after the treatment period. It can be concluded that debaters made small gains as compared to non-debaters, but their gains were not significantly greater than the gains of similar group of non-debaters. However, the lack of significant difference can be justified from different aspects:

First, to the researchers' assumption the limited time and low number of conducted debates which were inevitable during one term can be a reasonable justification for this lack of significant difference, while the limited time revealed the trend of improvement in students' critical thinking ability and the significant improvement in their reading comprehension, possibly a longer time can bring about better results. The studies done by (Brembeck, 1947; Jackson, 1961; Cross, 1971; and Colbert, 1986) in this line were all conducted over 6 months competition mostly with significant difference in gains. Although the current study failed to achieve significance, the small gains seem to be suggestive of a relationship between the two variables to motivate a further research.

Another possibility considered by the researcher for the lack of significant difference between the two groups on the posttest of critical thinking is that all the students in experimental group were novice debaters participating in debate for the first time. While in the above mentioned studies most students had experience in participating in debate. As Cross (1971) concludes from his study in which the participants were novice debaters, participating in the first semester of debate, while high participation in competitive debate enhances debaters' capacity in critical thinking, low participation may not excess critical thinking beyond the normal improvement in an academic year. Thus, low participation of some students might be a justified possibility for the low gains in critical thinking. This justification indicates that the intensity of time, and the low number of debate sessions for novice debaters are unlikely to reveal a significant gain in critical thinking. The above mentioned studies in which the experimental group outperformed the control group significantly were conducted during a long period of over 6 months of debate, with a high number of over 200 experienced debaters. These factors are considered as the limitations of this study contributing to the non-significant result.

As for the tools for assessing critical thinking ability, Facione (1992, cited in Reed, 1998) believes although all instruments for assessing critical thinking ability have been carefully developed and tested for reliability and validity 
having been widely used for testing people's thinking ability, "none have claimed to test for all aspects of critical thinking" (p.33).

Having the above discussion in mind and considering the lack of significant gains in critical thinking after applying debate in language classroom, the significant increase in reading comprehension of experimental group can be justified in two ways:

First, although debate has not revealed its significant effect statistically, considering its cognitive complexity, it might have indirectly affected the comprehension ability of the students which is again a complex cognitive skill. Pressley (2002) believes, little we know and teach about higher order thinking and reading comprehension. In Improving Comprehension Instruction he writes:

"We are far from knowing how to educate readers who will think hard about what they can do with ideas in texts, when they apply and when they do not. There needs to be a great deal of thinking about how students can be taught to be comprehenders that use what they read for intelligent decision making. We know more about comprehension strategies that promote simple memory of text than we do comprehension strategies that promote critical understanding of ideas in texts." (p.3)

Another interpretation is that students might have made benefits from the texts they had read and done some research in preparation for debate. Although the students did not get any comprehension strategies instruction, they were exposed to more reading materials as compared to control group. The materials included the texts given to them for debate and the texts they might have searched for gathering information for the debate. As a result, they were involved in more structures and new vocabulary than control group. All these can be contributing factors to improving reading comprehension. Dorn and Soffos (2005) believe that comprehension is a constructive process, personalized by the ideas and thoughts of the individual readers. They continue, ideas and thoughts cannot be taught; they can only be taught through personal connection:

"What can teachers do to promote comprehension? We can create a set of literal conditions that activate students' thinking process, but that is probably all we can do. The most important tool is the language teachers use to engage students in talking about books. Our classroom must be alive with literate task- rich conversation about books that apprentice students into deeper comprehension." Thus, according to these claims it is very likely that the students' comprehension ability has been improved by the debate in the classroom."

According to the results of the data analysis students who participated in debate sessions during the treatment period obtained significantly higher scores on reading comprehension posttest as compared to control group. Considering that students in this study did not receive any instruction on reading comprehension strategies, it can be concluded that using critical thinking skills can help them improve comprehension as a general cognitive skill, and process information at a deeper level.

As for the second question, bearing all the limitations, the study showed a small gain for experimental group resulting from the treatment. Despite the small difference between the two groups on (CTA) test, and considering all the limitations and restrictions imposed on the study, the findings showed that incorporating critical thinking skills in language classroom is vital to improve language teaching and learning. Every effort students made including being involved in reading materials, searching different sources, sharing opinions with others, cooperating in the classroom, and taking part in the argumentation for debate was a considerable contribution to triggering their thinking skills, in other words, activating their cognitive ability which led to the improvement of their reading comprehension. But before generalizing the result, the need is felt to conduct more research in the field of language teaching.

\section{PEDAGOGiCAL IMPLiCATIONS}

As it is strongly believed that teaching critical thinking skills is vital for the improvement of language proficiency, implementing critical thinking principles in the present study can be a creative inspiration to syllabus and material designers, teachers, students and test developers.

The result of the study can inspire the syllabus and material designers to include critical thinking issues both in students' text books and in teacher training courses. Learners are in need of text books that invoke their critical thinking and teachers need to be trained to change their attitudes toward students and themselves (Kabilan, 2000).

Concerning teachers, as they have an enormous responsibility in the classroom, it is crucially important that instead of being exam- oriented and producing learners who would obtain good results on their exams (Kabilan, 2000), they should be more flexible toward teaching, and they should consider students' attitudes, interests, and abilities encouraging them to use their thinking and express themselves critically and creatively.

The application of debate in language classroom shows the importance of domain knowledge in critical thinking. As it is stated in ADSA (2006, p.10), "Familiarity with the issue is the key aspect of preparation for debate ... "When the topic was introduced to the students they seemed to be unable to debate, but after they searched about the topic and equipped themselves with the related knowledge they were more eager to participate in the discussion, present brilliant ideas, pose clever questions, and show great ability in critical thinking.

The third side addressed in this study is the students who surprisingly enjoyed the program and after every session of debate they insisted on having a longer period and more sessions for debate. The program led the students to search for information relevant to the topics from different sources independently, while in normal classes they are highly 
dependent to the teachers and the text books. Searching for information would certainly encourage them think independently. The other advantage the students gained from the program was their participation in speaking during the debate sessions, so that even the reticent students were willing to express their own ideas. And finally, writing a report about the overall conclusion of the discussion was a useful activity, encouraging the students to use their writing skill expressing their ideas through writing. As Peirce (2005) cites Cohen, "debate can improve the four skills of the students-- speaking, listening, reading and writing." (p.4)

Test developers are also addressed in this study. Considering the backwash phenomenon in testing, as long as teachers are dependent to traditional testing which requires rote memorization, it would be useless to teach critical thinking skills in EFL contexts. Having in mind that the purpose of testing is to evaluate the teaching program and the improvement of the learners, this study inspires the test developers to bring about changes in testing, developing tests to affect the quality of teaching as well as improving the students ability to be creative in their performance on tests. One popular modal for test developing in critical thinking is Bloom's taxonomy which covers the requirements of testing in critical thinking program.

\section{REFERENCES}

[1] ADSA, (2006). Step-By-Step Guide to Debate. Retrieved September 14, 2008 from www.albertadebate.com

[2] Alexander, L. G. (1973). For and Against. London. Longman Group Limited.

[3] Barfield, K. D. (1989). A study of the relationship between active participation in interscholastic debating and the development of critical thinking skills with implications for school administrators and instructional leaders. Dissertation Abstract International, 50-09A:2714.

[4] Barnett, M. (1989). More than Meets the Eye: Foreign Language Reading. Language in Education: Theory and practice, no.73. CAL/ERIC Series on Language and Linguistics. Englewood Cliffs, NJ: Prentice Hall, Inc.

[5] Brembeck, W. (1947). The Effect of a Course in Argumentation on Critical thinking Ability. PhD. Dissertation. University of Wisconsin.

[6] Celce-Murcia, M. (2001). Teaching English as a second or foreign language. (3rd ed.). MA: Heinle \& Heinle.

[7] Colbert, K. (1986). The Effect of CDEA and NDT Debate Training on Critical Thinking Ability. PhD. Dissertation, Florida State University.

[8] Cross,G,. (1971). The Effect of Belief Systems and the Amount of Debate Experience on the Acquisition of Critical Thinking. PhD Dissertation, University of Utah.

[9] Davidson, B. (1995). Critical Thinking Education Faces the Challenge of Japan. Retrieved September 14, 2008 from http://www.chss.montclair.edu/inquiry/spr95/davidson.html

[10] Djuranovic, M. (2003). The Ultimate Lincoln- Douglas Debate Handbook. Retrieved Sep 16, 2008 from www.iddebate.net/ thirdedition.pdf.

[11] Dorn, L. J., \& Soffos, C. (2005). Teaching for Deep Comprehension: A reading workshop approach. Portland, Maine, Stenhouse Publishers. Retrieved Sep 14, 2008 from www.stenhouse.com

[12] Durkin, D. (1993). What classroom observations reveal about reading comprehension instruction. Reading Research Quarterly, 14, 481-533.

[13] Facione, P. A., (1992). Critical Thinking: What it is and why it counts. Retrieved March 1, 2008, from http://insightassessment.com/t.html

[14] Freeley, A. J., \& Steinberg, D. L. (2000). Argumentation and debate: Critical thinking for reasoned decision making. (10th ed.). Stamford: Wadsworth.

[15] Fukuda,,S. (2003). Attitudes towards argumentation in college EFL classes in Japan: Proceedings of the First Asia TEFL International Conference. Retrieved March 1, 2008, from http://www.rapidintellect.com/AEQweb/spurn4.html

[16] Grabe,W.(1991). Current development in second language reading research. TESOL Quarterly 25(3), 375-406

[17] Halvorsen, A. (2005). Incorporating critical thinking skills development in to ESL/EFL courses. Internet TESL Journal, 11(3). Retrieved September 14, 2008, from http://iteslj.org/Techniques/HalvorsenCriticalThinking.html

[18] Haines, S., \& Stewart, B. (2000). Landmark Intermediate Student's Book. UK. Oxford University Press.

[19] Jackson, T. (1961). The Effects of Intercollegiate Debating on Critical Thinking. PhD. Dissertation. University of Wisconsin.

[20] Kabilan, M. K. (2000). Creative and critical thinking in language classroom. The Internet TESL Journal 6(6). Retrieved September 14, 2008, from http://iteslj.org/Techniques/

[21] Krieger, D. (2005).Teaching debate to ESL students: A six - Class Unit. The Internet TESL Journal, 11(2). Retrieved September 14, 2008, from http://iteslj.org/Techniques/

[22] Paul, R. (1990). Critical Thinking: What every person needs to survive in a rapidly changing world. Rohnert Park. CA: Center for critical thinking and moral critique.

[23] Paul, R. (2004). The state of critical thinking today: the need for a substantive concept of critical thinking. Retrieved July 15, 2009 from www.criticalthinking.org

[24] Peirce, B. (2005). Handbook of critical thinking resources. Retrieved September 14, 2008, from www.criticalthinking.org/aboutCT/definingCT.shtml...

[25] Pressley, M. (2002). Metacognition and Self-Regulated Comprehension, Chapter 13, in Farstrup, A. E. \& Samuels, S. Jay (2002). What research has to say about reading instruction? Newark, Del: International Reading Association.

[26] Reed, J. H. (1998). Effect of a model for critical thinking on students' achievement in primary source document analysis. (a $\mathrm{PhD}$ dissertation) University of south Florida. Retrieved March 28, 2008 from www.criticalthinking.org

[27] Robinson, D.J. (2006). The Paideia Seminar: Moving reading comprehension from transaction to transformation. Dissertation $\mathrm{PhD}$, University of Massachusetts, Lowell. 
[28] Schafersman, S. D. (1991). An introduction to critical thinking. Retrieved March 3, 2008 from www.freeinquiry.com/critical.html

[29] Wegmann, B., \& Knezevic, M. (2002). Mosaic 1 Reading. (4th ed.). NY: McGraw - Hill Companies, Inc.

[30] Willingham, D. T. (2007). Critical thinking: why is it so hard to teach? American Educator, 33(2), 8-19.

[31] Wright, I. (2002). Is that right? Critical Thinking and the social world of the young learner. Toronto: Pippin Publishing Corporation.

Mansoor Fahim was born in Nahavand in 1946. He received a Ph.D. in TEFL from Islamic Azad University in Tehran, Iran in 1993.

As for his professional background, he was a member of the faculty of English Language and Literature at Allameh Tabataba'i University in Tehran, Iran from 1981 to 2008 when he was retired as an associate professor of TEFL. He has taught English at a welter of universities. At present, he runs Research methods, Psycholinguistics, Applied Linguistics, Second Language Acquisition, and Seminar classes at MA .level and First Language Acquisition, Psycholinguistics, and Discourse Analysis courses at Ph.D. level at a number of universities including Allameh Tabataba'i and Islamic Azad Universities, Science and Research Campus. Moreover, he has several published articles and books mostly in the field of TEFL and has translated some books into Farsi.

Dr. Fahim is currently a member of the editorial board of some Iranian journals of Applied Linguistic Studies.

Maryam Sa'eepour was born in Khorramshahhr, Iran in 1960. She received her MA degree in teaching English as a foreign language from Khatam State University, Iran in 2009.

Her thesis article was accepted and presented in the English as an International Language Conference, in Izmir, Turkey, 2009.

Maryam Sa'eepour has been teaching EFL courses in different institutes, and she is currently teaching in Iranian colleges. 